\title{
Augmentasi Silikon pada Hidung Pelana
}

\author{
Jacky Munilson, Effy Huriyati, Sri Mulyani
}

\begin{abstract}
Abstrak
Hidung pelana merupakan salah satu tantangan dalam bedah rinoplasti. Hidung pelana dapat disebabkan oleh beberapa faktor seperti trauma, infeksi dan iatrogenik. Pembedahan bertujuan untuk mengoreksi kelainan bentuk fisiologi serta meningkatkan aspek estetik dan emosional. Metode: Satu kasus hidung pelana pada anak perempuan usia 14 tahun yang yang telah ditatalaksana dengan rinoplasti eksterna dan augmentasi silikon. Hasil: Terdapat perbaikan kosmetik pada hidung pelana. Diskusi: Tujuan utama penatalaksanaan hidung pelana adalah meningkatkan penampilan hidung dengan mempertahankan fungsi hidung.
\end{abstract}

Kata kunci: hidung pelana, rinoplasti eksterna, silikon

\begin{abstract}
Saddle nose is one of the most challenging in all of rhinoplasty surgery. Saddle nose may be caused by many factors: traumatism, infection and iatrogenic. Surgical intervention is required to correct the anatomic and physiologic disorder andd improve the aesthetic and emotional aspect. Methods: A case of saddle nose in a 14 years olg girl had been treated by external rhinoplasyi and augmentation of of silicone. Results: There cosmetic repairs on the saddle nose. Discussion: The main objective the management of saddle nose was to improve the appearance of the nose and maintain nasal function.
\end{abstract}

Keywords: saddle nose, open rhinoplasty, silicone

Affiliasi penulis : Bagian THT-KL Fakultas Kedokteran Universitas Andalas

Korespondensi : Sri Mulyani, email : ummi.sri@gmail.com, Telp: 081374112916

\section{PENDAHULUAN}

Struktur anatomi hidung yang merupakan proyeksi wajah rentan terhadap trauma. Pola anatomi hidung normal relatif dan tergantung pada biotipe manusia. Hidung dibentuk oleh dua bagian: bagian mobil (kartilago) dan bagian yang tetap (tulang). Secara fisiologi fungsi hidung adalah menghangatkan, membersihkan dan melembabkan udara pernafasan. ${ }^{1}$

Jika terdapat deformitas pada dorsum nasi seperti hidung pelana, skoliosis, deviasi septum atau anomali kongenital akan menimbulkan kelainan fisiologi bahkan gangguan sistemik. Hidung pelana dapat disebabkan oleh trauma yang diikuti oleh abses septum, infeksi seperti lepra, sifilis, tuberkulosis dan blastomikosis bahkan iatrogenik yang biasanya dari operasi orbito nasofrontal. ${ }^{1,2}$
Trauma hidung dapat menimbulkan hematom septum karena robeknya pembuluh darah yang berbatasan dengan tulang rawan septum sehingga darah akan terkumpul pada ruang antara tulang rawan dengan mukoperikondrium. Hematom septum dapat terinfeksi sehingga terbentuk abses septum yang akan menyebabkan nekrosis tulang rawan septum dan digantikan oleh jaringan ikat. Hilangnya penyangga pada dorsum nasi akan menimbulkan hidung pelana. Kelainan ini dapat diperbaiki dengan septorinoplasti, jika diperlukan dapat menggunakan implan sebagai bahan penambal biomaterial untuk memperbaiki deformitas hidung agar tampak normal. ${ }^{3}$

Tujuan utama penatalaksanaan hidung pelana adalah meningkatkan penampilan hidung dengan mempertahankan fungsi hidung. ${ }^{4,5}$

\section{LAPORAN KASUS}

Seorang anak perempuan usia 14 tahun datang ke poliklinik THT-KL RS Dr. M. Djamil Padang pada tanggal 4 Juli 2011 dengan keluhan utama 
hidung pesek sejak 2 bulan sebelum masuk rumah sakit. Pasien rujukan dari RS Ahmad Muchtar Bukittinggi dengan diagnosis pasca insisi abses septum dan rekonstruksi septum nasi dengan graft dari kartilago konka aurikuler sinistra. Tiga bulan sebelum masuk rumah sakit, pasien mengalami benjolan pada kedua lubang hidung yang makin lama makin besar sehingga pasien sulit bernafas. Nyeri pada hidung disertai demam dan telah berobat ke bidan dan RS daerah tetapi tak ada perbaikan. Pasien mempunyai riwayat mengorek hidung sebelumnya. Pasien dirujuk ke RS Dr. Ahmad Muchtar Bukittinggi dan dilakukan aspirasi dan insisi abses serta dipasang tampon hidung. Empat hari setelah tindakan dilakukan rekonstruksi septum dengan pemasangan graft dari kartilago konka aurikuler pada septum nasi. Setelah operasi pasien mengeluh hidung makin pesek. Hidung tersumbat dan gangguan penciuman tidak ada.

Pemeriksaan fisik didapatkan keadaan umum pasien sedang, komposmentis kooperatif, suhu $36,7^{\circ} \mathrm{C}$. Pemeriksaan telinga dan tenggorok dalam batas normal. Pemeriksaan hidung luar ditemukan adanya deformitas pada dorsum nasi, depresi dari rinion, krepitasi tidak ada, kulit normal, aliran udara lancar, sudut frontonasal: $140^{\circ}$, sudut nasolabial: $70^{\circ}$ dan proyeksi tip: 12 (gambar 1). Kavum nasi dekstra lapang, konka inferior dan konka media eutrofi, warna merah muda. Kavum nasi sinistra sempit, konka inferior eutrofi, warna merah muda, konka media eutrofi, septum terdapat krista. Pasien didiagnosis kerja dengan hidung pelana. Pasien direncanakan rinoplasti eksterna.

sudut frontonasal

$\rightarrow 140^{\circ}$

Sudut nasolabial

$\rightarrow 70^{\circ}$

Proyeksi tip

$\rightarrow 12$

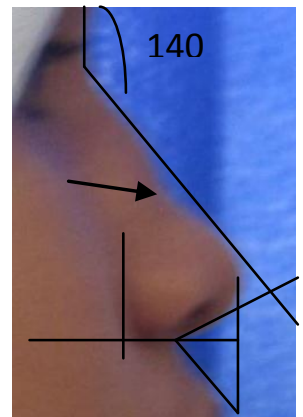

Gambar 1. Analisa hidung sebelum operasi (tampak hidung pelana)
Pemeriksaan laboratorium darah tanggal 12 Juli 2011 didapatkan hasil Hb: 13,4 gr\%, leukosit: 9.200/ $\mathrm{mm}^{3}$, hematokrit: $42 \%$, trombosit: $343.000 / \mathrm{mm}^{3}$, PT: 10,7 detik dan APTT: 41,1 detik. Hasil pemeriksaan Rontgen sinus paranasal dan os nasal didapatkan deviasi septum nasi ke kiri dan os nasal intak (gambar 2).

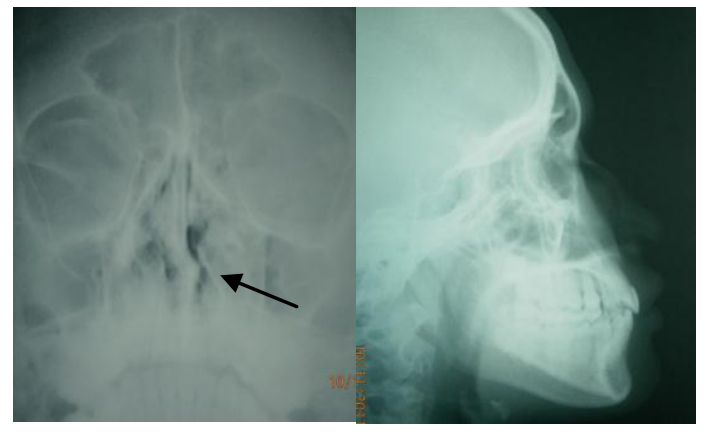

Gambar 2. Rontgen sinus paranasal dan os nasal.

Tanggal 25 Juli 2011 dilakukan operasi rinoplasti eksterna. Operasi dimulai dengan pasien tidur telentang di meja operasi dalam narkose. Dilakukan tindakan asepsis dan antisepsis pada lapangan operasi. Evaluasi kavum nasi dengan nasoendoskop, tampak kavum nasi dekstra lapang, konka inferior dan konka media eutrofi, deviasi septum minimal. Kavum nasi sinistra sempit, konka inferior dan konka media eutrofi, terdapat krista premaksila pada septum. Dilakukan infiltrasi dengan adrenalin 1 : 200.000 pada mukosa septum sinistra dan dekstra namun cairan adrenalin sulit masuk kemungkinan karena adanya perlengketan mukosa septum. Dilakukan septoplasti open book dengan membuat insisi vertikal di anterior krista dilanjutkan dengan insisi horizontal sepanjang krista. Dilakukan pelepasan mukosa septum sisi kiri dan kanan. Setelah kartilago septum terpapar dilakukan reseksi krista premaksila dan disiapkan untuk graft. Sebagian mukosa septum sudah tidak ada. Dilanjutkan dengan rinoplasti eksterna. Dilakukan infiltrasi dengan adrenalin 1:200.000 pada kolumela. Dibuat insisi inverted $\mathrm{V}$ di daerah kolumela dengan menggunakan pisau no.15 dilanjutkan dengan insisi marginal dan dilebarkan dengan menggunakan gunting sudut, di atas kartilago ala krus 
medial dengan diseksi (tajam), dilanjutkan ke krus lateral kartilago alar, kartilago lateral atas dorsum nasi sampai dengan sudut fronto-nasal terpapar. Graft yang diambil dari kartilago septum nasi dicoba dipasangkan pada dorsum nasi tetapi tidak mencukupi untuk menutupi dorsum nasi sehingga diputuskan untuk memakai silikon. Silikon dibentuk seperti bumerang dan diukur panjangnya mulai dari os nasal sampai kolumela. Silikon dipasang pada dorsum nasi. Luka pada kolumela dan insisi marginal dijahit dengan prolen 5.0. Hidung ditampon dengan tampon yg sudah dilapisi oleh salep antibiotik. Dipasang steril strip pada dorsum nasi. Operasi selesai.

Pasien didiagnosis dengan pasca rinoplasti eksterna dengan pemasangan silikon atas indikasi hidung pelana. Diberikan terapi injeksi Seftriakson 2x1 gr intravena (skin test), injeksi deksametason $3 \times 5 \mathrm{mg}$ intravena, injeksi ranitidin $2 \times 50 \mathrm{mg}$ intravena, drip tramadol $100 \mathrm{mg}$ dalam ringer laktat.

Tanggal 30 Juli 2011 tampon anterior hidung dibuka. Tampak kavum nasi dekstra lapang, konka inferior dan konka media eutrofi, darah mengalir tidak ada, sinekia tidak ada, septum di tengah. Pada kavum nasi sinistra tampak kavum nasi lapang, konka inferior dan konka media eutrofi, darah mengalir tidak ada, sinekia tidak ada, mukosa septum yang dielevasi menempel pada septum, perforasi septum tidak ada, hematom septum tidak ada. Pasien pulang dan diberi terapi sefiksim $2 \times 100 \mathrm{mg}$, metil prednisolon $3 \times 4 \mathrm{mg}$ dan sirup ibuprofen $3 \times 100 \mathrm{mg}$

Tanggal 1 Agustus 2011 pasien kontrol, tidak ada keluhan hidung tersumbat, demam, gatal dan merah pada hidung. Hidung luar tertutup steril strip. Pada kavum nasi dekstra lapang, konka inferior dan konka media eutrofi, deviasi septum tidak ada. Kavum nasi sinistra lapang, konka inferior dan konka media eutrofi, terdapat krista minimal pada septum. Luka bekas jahitan pada kolumela kering. Pasien didiagnosis dengan pasca rinoplasti eksterna dengan pemasangan silikon atas indikasi hidung pelana. Luka jahitan pada kolumela dibuka dan diberi terapi sefiksim 2x100 mg dan metil prednisolon 3×4 mg.

Tanggal 8 Agustus 2011 pasien kontrol, tidak ada keluhan hidung tersumbat, demam, gatal dan merah pada hidung. Hidung luar tertutup steril strip. Pada kavum nasi dekstra lapang, konka inferior dan konka media eutrofi, deviasi septum tidak ada. Kavum nasi sinistra lapang, konka inferior dan konka media eutrofi, tampak krista minimal pada septum. Dilakukan pengangkatan steril strip, tampak bintik-bintik putih pada dorsum nasi, tidak ada deformitas, udem dan gatal. Pasien didiagnosis dengan pasca rinoplasti eksterna dengan pemasangan silikon atas indikasi hidung pelana dan dermatitis kontak iritan, diberi terapi sefiksim 2x100 mg dan loratadin $1 \times 10 \mathrm{mg}$.

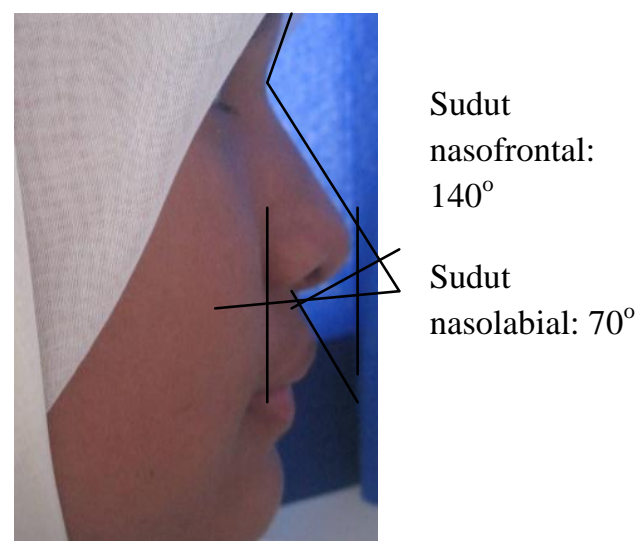

Gambar 3. Analisa hidung setelah operasi, tak ada hidung pelana

Tanggal 15 September 2011 pasien kontrol, terdapat keluhan bersin-bersin lebih dari 5 kali terutama pagi hari disertai pilek. Gejala timbul kurang dari 4 kali per minggu dan mengganggu aktifitas sehari-hari. Tidak ada hidung tersumbat, demam, gatal dan merah pada hidung. Hidung luar tidak terdapat deformitas, kulit normal. Pada kavum nasi dekstra lapang, konka inferior dan konka media eutrofi. Kavum nasi sinistra lapang, konka inferior dan konka media eutrofi, terdapat krista minimal pada septum. Pasien dikonsulkan ke subbagian alergi dan imunologi THT$\mathrm{KL}$. Dilakukan pemeriksaan cukit kulit dengan hasil alergi terhadap blomia tropicalis dan kacang. Pasien didiagnosis dengan pasca rinoplasti eksterna dengan pemasangan silikon atas indikasi hidung pelana dan rinitis alergi intermiten sedang berat dan diberi terapi sefiksim $2 \times 100 \mathrm{mg}$, setirizin $1 \times 10 \mathrm{mg}$ dan semprot hidung flutikason furoat $1 \times 2$ semprot pada hidung kiri dan kanan. 


\section{DISKUSI}

Dilaporkan satu kasus hidung pelana pada anak perempuan umur 14 tahun yang ditegakkan melalui anamnesis dan pemeriksaan THT-KL.

Abses septum nasi biasanya disebabkan oleh trauma, komplikasi operasi hidung, infeksi sinus, furunkel intranasal, infeksi gigi dan kelainan imunologi. ${ }^{3}$ Pada pasien ini hidung pelana disebabkan oleh abses septum nasi yang didahului oleh trauma yaitu mengorek hidung. Abses septum pada pasien ini telah menimbulkan komplikasi perforasi septum dan telah dilakukan rekonstruksi septum dengan menggunakan graft dari kartilago konka aurikuler tetapi tidak mampu menyangga dorsum nasi sehingga terjadi hidung pelana.

Ada beberapa variasi klasifikasi hidung pelana, salah satunya menurut Emsen seperti yang dikutip oleh Mao, ${ }^{6}$ hidung pelana dibagi atas 4 derajat yaitu derajat I: hilangnya penyangga septum dan retraksi kolumela, derajat II: hilangnya proyeksi puncak hidung dan nostril, derajat III: datarnya puncak hidung, hidung memendek dan deformitas pada dasar hidung serta pada derajat IV: telah melibatkan tulang dengan hilangnya penyangga lobular, hilangnya puncak hidung, memendek dan berputar. Pada pasien ini hidung pelana merupakan derajat I karena hanya melibatkan penyangga septum saja.

Edwin Smith seperti yang dikutip oleh Vartanian $^{2}$, pertama kali menemukan penatalaksanaan deformitas hidung. Rekonstruksi hidung pertama kali dilakukan oleh bangsa India pada tahun 800 SM. Penatalaksanaan hidung pelana dengan rinoplasti berkembang sampai abad 19 .

Ada dua pendekatan pada rinoplasti yaitu pendekatan endonasal dan pendekatan eksternal. Pendekatan endonasal mempunyai keuntungan diantaranya tidak adanya insisi eksternal, sedikit diseksi, kurangnya trauma jaringan lunak dan jaringan parut. Seperti yang dikutip oleh Vuyk, ${ }^{5}$ pendekatan eksternal pertama kali diterangkan dalam literatur Eropa oleh Rheti (1934) dan Sercer (1958). Padovan (1966) memperkenalkan pendekatan eksternal di Amerika Serikat dan Kanada. Keuntungan pendekatan eksternal ini diantaranya mudah mengangkat kulit dan jaringan lunak dari rangka hidung. Pada pendekatan eksternal paparan lebih baik sehingga kartilago lower lateral dan media terlihat dengan jelas dan anatomi dapat diperbaiki serta penempatan dan fiksasi graft lebih baik. ${ }^{7,8}$

Pada kasus ini sebelumnya telah dilakukan rekonstruksi hidung dengan menggunakan graft dari kartilago konka aurikuler tetapi gagal, kemungkinan disebabkan graft diresorbsi sehingga tidak dapat menyangga dorsum nasi. Setelah itu dilakukan rinoplasti eksterna dengan alasan supaya paparan dorsum nasi lebih luas sehingga mudah menempatkan graft (silikon).

Untuk hidung pelana derajat I dan II, dengan kehilangan minimal penyangga dorsum, puncak hidung, proyeksi, retraksi kolumelar dan nostril memerlukan graft kartilago atau tulang septum atau kartilago konka aurikuler untuk augmentasi dorsum nasi. Hidung pelana derajat III dan IV biasanya membutuhkan struktur yang lebih kaku seperti tulang atau iga. ${ }^{6}$

Pemilihan bahan yang dipakai untuk augmentasi dosum nasi penting dalam koreksi kelainan hidung pelana. Bahan yang dipakai dapat berupa autograft, homograft, dan alloplast. Autograft merupakan standar baku emas untuk augmentasi pada rinoplasti eksterna. Autograft dipakai karena respon inflamasi sedikit dengan derajat resorbsi, ekstrusi, dan infeksi yang rendah.,

Ada beberapa bahan autograft yang dapat digunakan diantaranya: 1. kartilago seperti septum, konka aurikular, iga, 2. tulang seperti kalvaria, iliaka, hidung, 3. Jaringan lunak seperti dermis, fasia dan lemak. $^{9,10}$

Ada banyak keuntungan graft dari kartilago atau tulang septum diantaranya risiko lebih kecil, mudah didapat yaitu dari septum kecuali pada pasien dengan perforasi septum atau telah dilakukan septoplasti sebelumnya. Reaksi penolakan sedikit karena merupakan jaringan yang alami pada area tersebut. Adapun kerugian dari graft kartilago septum adalah kemungkinan bentuk yang ireguler pada kulit hidung yang tipis dan risiko terbentuknya hidung pelana akibat pengambilan graft yang agresif. ${ }^{6}$

Keuntungan graft dari kartilago konka aurikuler hampir sama dengan graft septum, pengambilan bahan cepat, mudah, risiko rendah, menyokong lebih adekuat dan lebih elastis. Kerugian yang utama 
dari graft konka aurikuler adalah adanya penambahan insisi dan diseksi dan graft dapat bergeser sehingga menyebabkan dorsum nasi yang asimetris. ${ }^{6}$

Kartilago iga juga merupakan pilihan yang baik untuk augmentasi tetapi mempunyai kerugian diantaranya nyeri pada donor dan adanya risiko pneumotoraks sehingga graft ini jarang dipakai. ${ }^{4}$

Bahan homograft terdiri atas 2 jenis yaitu kartilago iga yang diradiasi dan alloderm. Kartilago iga yang diradiasi mempunyai keuntungan diantaranya derajat infeksi dan ekstrusi yang rendah, respon imunologi yang minimal. Jenis graft ini akan diresorbsi dalam jangka waktu yang lama dan graft berpotensi untuk melengkung. Untuk mengurangi risiko graft melengkung diatasi dengan pengangkatan perikondrium dan korteks luar iga. Alloderm merupakan graft dari struktur ekstraselular dermis yang dipakai untuk menutupi jaringan lunak yang ireguler atau untuk menutupi implan lain. Keuntungannya aman, tidak ada reaksi penolakan dan risiko infeksi. Kerugiannya tingkat resorbsi yang tinggi dan bukan merupakan jaringan penyangga yang baik. ${ }^{9,10}$

Alloplast mempunyai beberapa keuntungan diantaranya, ketersediaan yang banyak, berkurangnya waktu operasi dan kesakitan donor. Bahan alloplast terbagi atas: 1. polimer seperti silikon, polietilen, politetrafluoroetilen, poliester, poliamides, 2. Bahan yang dapat diserap seperti benang, metiselulosa dan gelfoam. ${ }^{10,11}$

Kipping, seperti yang dikutip oleh Duffi, ${ }^{12}$ merupakan ahli kimia Inggris pertama yang memberikan istilah silikon untuk menggambarkan suatu senyawa polimer sintetis yang menggunakan bahan dasar silikon (atom nomor 14). Silikon secara kimia terdiri elemen alami silikon, oksigen dan hidrogen. Viskositas senyawa ini ditentukan oleh panjang rantai dan derajat ikatan molekul atau polimerisasinya. Silikon tersedia dalam bentuk padat, dan cair.

Silikon cair bersifat permanen, non karsinogenik, antigenik minimal, tidak baik untuk pertumbuhan kuman, tidak bereaksi dengan paparan sinar matahari atau bahan kimia lain, dapat disterilkan dan derajat viskositas tidak berubah karena perubahan suhu tubuh. Tetapi terdapat banyak komplikasi yang dilaporkan dari pemakaian silikon cair ini diantaranya pneumonitis, nodul di kulit dan granuloma (silikonoma). ${ }^{13}$

Silikon padat lebih banyak dipakai untuk augmentasi karena permukaan lembut dan licin, mudah dibentuk, lebih alami, pemakaian lebih mudah, waktu operasi lebih sedikit dan mudah diangkat jika terjadi komplikasi. ${ }^{9,11}$

Silikon padat menghasilkan struktur penyangga yang lebih baik dan merupakan bahan alloplast pertama yang diterima secara luas dalam bedah plastik wajah. Meskipun silikon padat merupakan bahan yang bio-inert tetapi strukturnya tidak berpori sehingga risiko untuk infeksi meningkat dan kemungkinan terjadinya ekstrusi lebih besar karena adanya ruang antara graft dengan jaringan host. Akan tetapi, silikon sangat terkenal pemakaiannya untuk augmentasi penduduk Asia. Keberhasilan ini karena pada penduduk Asia mempunyai jaringan kulit yang relatif tebal untuk menutupi implan. ${ }^{10,14}$

Pada pasien ini graft yang dipilih pada awalnya adalah kartilago septum tetapi karena tidak cukup untuk menutupi defek pada dorsum nasi dan karena kartilago konka aurikuler sudah pernah dicoba tetapi tak berhasil dan kartilago iga lebih invasif sehingga diputuskan memakai silikon padat karena mudah dibentuk, permukaan licin dan pemakaian lebih mudah.

Seperti yang dikutip oleh Lin, ${ }^{10}$ Ham dalam penelitiannya pada 1500 kasus augmentasi rinoplasti dengan menggunakan silikon ditemukan 18\% komplikasi yang disebabkan oleh rancangan bentuk implan atau teknik operasi yang kurang. Semua komplikasi dini $(6,6 \%)$ terjadi dalam 2 minggu yaitu infeksi kuman Stafilococcus aureus. Komplikasi mayor terjadi setelah 4 minggu $(62,4 \%)$ diantaranya perubahan warna kulit menjadi putih, eritema dan penipisan kulit. Komplikasi lain termasuk malposisi $(8,5 \%)$ dan ekstrusi (7,5\%). Wang ${ }^{9}$ (2003-2005) melaporkan komplikasi silikon 5,6\%-16\% dan komplikasi yang tersering adalah infeksi, pergeseran, ekstrusi dan penonjolan silikon yang berlebihan.

Rinoplasti eksterna mempunyai risiko terjadinya nekrosis skin flap kolumela dan terbentuknya parut kolumela. ${ }^{5,15}$ Menurut Foda seperti yang dikutip oleh Gendeh, ${ }^{7}$ komplikasi rinoplasti eksterna diantara- 
nya adalah flap septum yang robek $2,8 \%$, cedera kartilago alar $1,8 \%$, trauma nasal post operasi $1 \%$, epistaksis $2 \%$, infeksi $2,4 \%$, edema $17 \%$, obstruksi hidung $0,8 \%$, parut transkolumelar $0,8 \%$. Tingkat kepuasan pasien 95,6\%. Pada pasien ini tidak ditemukan komplikasi dari pemakaian silikon seperti infeksi, perubahan warna kulit, eritema dan penipisan kulit. Juga tidak ditemukan adanya komplikasi rinoplasti tetapi terdapat dermatitis kontak iritan disebabkan karena pemakaian steril strip yang lama yaitu 14 hari yang seharusnya hanya 7 hari. Ini dapat diatasi dengan pemberian anti histamin.

Pada evaluasi 2 bulan pasca operasi, pasien merasa puas dengan hasil operasi rekonstruksi hidung yang dilakukan dan tidak terdapat gangguan fungsional terhadap hidung.

\section{DAFTAR PUSTAKA}

1. Almeida FS, Minarro LL, Pialarissi PB, Shirane E. Surgical correction of the saddle nose: case report. Int arch of otorhinolaryngology 2009; 13(4): 1-6.

2. Vartanian AJ. Saddle nose rhinoplasty. Available from http://emedicine.medscape.com/article/84091 0-overview. Update: Jun 30, 2010.

3. Trimartani, Sawitra D. Septorinoplasti: penanganan komplikasi abses septum akibat trauma. Otorhinolaryngologica Indonesiana 2000; 30(3): 21-8.

4. Taylor SM, Rigby MH. The Taylor saddle effacement: a new technique for correction of saddle nose deformity. Journal of otolaryngology-head \& neck surgery 2008; 37(1): 105-11.

5. Vuyk HD, Kalter PO. Open septorhinoplasty: experiences in 200 patient. Rhinology 1993;
31: 175-82.

6. Mao J, Carron M, Tomovic S, Narasimhan K, Allen $\mathrm{S}$, Mathog $\mathrm{RH}$. Cartilage grafts in dorsal nasal augmentation of traumatic saddle nose deformity: a long term follow-up. The laryngoscope 2009; 119: 2111-7.

7. Gendeh BS, Tan VES. Open septorhinoplasty: operative technique and grafts. Med J Malaysia 2007; 62(1): 13-8.

8. Darwish A, Moghazy AE, Mahrous A. Open rhinoplasty: versatility of the technique. Eqyptian journal of surgery 2005; 24(4): 1847.

9. Romo T, Pearson JM. Nasal implant. Fasial plast surg clin n am 2008; 16: 123-32.

10. Lin G, Lawson W. Complications using grafts and implants in rhinoplasty. Operative techniques in otolaryngology 2007; 18: 315 23.

11. Wang JH, Lee BJ, Jang YJ. Use of silicone sheets for dorsal augmentation in rhinoplasty for Asian noses. Acta oto-laryngologyca 2007; 558: 115-20.

12. Duffy DM. Liqiud silicone for soft tissue augmentation. Dermatol surgery 2005; 31 : 1530-41.

13. Narins RS, Beer K. Liquid injectable silicone: a review of its history, imunology, technical considerations, complications and potential. Plast reconsr surg 2006; 118: 77S-84S.

14. McCurdy JA. Augmentation rhinoplasty with silicone protheses. Operative techniques in otolaryngology 2008; 19: 72-8.

15. Fernandes SV. Complications of rhinoplasty. Available from http://emedicine.medscape.com/article/84343 9-overview. Update: Apr 26, 2011. 